\title{
Marketing Innovation: A Systematic Review
}

\section{Sharon Purchase, UWA Business School, University of Western Australia \\ Thierry Volery, Zurich University of Applied Sciences (ZHAW) and UWA Business School, University of Western Australia}

\begin{abstract}
This study aims to investigate the development of 'marketing innovation' defined as the implementation of new marketing practices involving significant changes in the design, distribution, promotion or pricing of a product or service. Drawing on a sample of 289 articles, we conduct a systematic review to provide conceptual, methodological and thematic guidance for scholars interested in studying marketing innovation. Our findings suggest while marketing innovation is often merged with the dominant technological focus underpinning product or service innovation, there is a growing trend to consider the innovation potential offered by the development of new distribution channels, branding strategies, communication types or pricing mechanisms. Digitisation, a key driver for marketing innovation, enables new communication methods, branding strategies, offering designs, and transaction settings. We find that the resource-based view, market orientation and diffusion of innovation perspectives have been the favoured theoretical anchors used to investigate marketing innovation. Yet, there is a growing trend to focus on co-creation, service-dominant logic and user community perspectives.
\end{abstract}

Keywords: marketing innovation; innovation; new marketing processes

\section{INTRODUCTION}

Innovation and marketing have often been seen as the two sides of the coin. Half a century ago, Drucker remarked: "Because the purpose of business is to create a customer, the business 
enterprise has two -and only two- basic functions: marketing and innovation. Marketing and innovation produce results; all the rest are costs” (Drucker, 1954, p. 39.) Not surprisingly, innovation has been a pervasive topic in the marketing literature. The primary reason underpinning the inextricable link between marketing and innovation stems from the nature and overlap of both disciplines (Foxall, 1988). Innovation is an iterative process initiated by the perception of a problem or unmet customers' needs which leads to the development, production, and marketing of an offering addressing this opportunity. Innovation, therefore, includes not only market research, but also invention, production development, commercialisation, and subsequent product adaptation and upgrading (Garcia \& Calantone, 2002; Thornhill, 2006).

Despite the extensive development of product (goods and services) and process innovations, little attention has been paid to novel marketing strategies (Geldes, Felzensztein, \& PalaciosFenech, 2017; Claudy, Garcia, O’Driscoll, 2015). However, evidence of such marketing innovation is plentiful: it includes significant changes in the design and packaging of products (e.g., refill detergent bottles, interactive packaging with QR codes, labels with invisible watermarks to check product authenticity, fully recyclable or compostable packaging), new media or techniques for product promotion (e.g., social media contests, shared customer reviews, personalised advertising using geolocation), new methods for product distribution (e.g., direct sales, live demonstration, multilevel network marketing plans) and new ways of pricing goods and services (e.g., pre-paid, flat rate, dynamic pricing).

There have been numerous calls recently to investigate marketing innovations which originate from novel ways in which products or services are designed, priced, distributed and/or promoted (Brexendorf, Bayus, \& Keller, 2015; Grimpe, Sofka, Bhargava, \& Chatterjee, 2017; Nguyen, Yu, Melewar, \& Chen, 2015). Concurrently, the proliferation of existing concepts and the ambiguity in the way in which marketing innovation concepts are operationalised has led 
to some confusion in directly comparing empirical work, requiring researchers to articulate the terminology used. Marketing managers often experience difficulty understanding the nature of marketing innovation, its antecedents and consequences.

Our review addresses this gap by conducting a systematic analysis of the marketing innovation literature. In doing so, we provide conceptual, methodological and thematic guidance for scholars interested in studying marketing innovation. We draw on the literature in marketing, and business management to examine the intersection of marketing and innovation. Instead of developing a new typology, we aim to synthetise existing concepts and to provide a parsimonious framework of the overarching factors at the core of marketing innovation.

\section{Defining marketing innovation}

Marketing innovation has been considered from multiple perspectives in both policy and academic literature. Policy makers, such as international organisations and government agencies, include marketing innovation within their various reports (e.g., European Innovation Scoreboard, (European Union, 2017); Global Innovation Index, (Cornell University, INSEAD, \& WIPO, 2018); and Community Innovation Survey conducted by the European Commission). These various reports draw on definitions outlined in the Oslo Manual (OECD, 2005; 2018) and consider marketing innovation as a single item or within an umbrella innovation concept.

However, as shown in Table 1, there has been some variation in conceptualising marketing innovation in the academic literature. In Table 1, while direct quotations have been drawn from the literature, articles which use a similar or the same definition have also been included in the references. Numerous definitions have been offered, encompassing either specific (e.g. customer management) or broader marketing practices. The majority of authors listed in Table 1 define marketing innovation as new marketing methods involving either the 4Ps of marketing or some combination thereof. For example Gupta, Malhotra, Czinkota, \& Foroudi (2016) 
incorporate the 4Ps plus marketing information systems and Weerawardena (2003) includes entering new markets. Nevertheless, the most commonly cited definition of marketing innovation follows the Oslo Manual (2005), namely the implementation of new marketing practices involving significant changes in the design, packaging, distribution, promotion or pricing of a product or service.

This research aims to take a broad perspective at marketing innovation and to draw on a definition that will have the following attributes: used by both practitioner and academic audiences, widely recognised within the academic literature, encompass a broad range of articles focusing on marketing innovation, and used regularly to allow comparison of results. A broad definition will allow us to capture the nuances of marketing practices within the literature review. Given that the majority of articles incorporate aspects of the 4Ps within their definitions and that the OECD (2005) definition draws on the same aspects and is commonly cited both within academic and policy literature, this research will follow this definition.

In addition, the OECD definition is the "most widely accepted" (Medrano \& Olarte-Pascual, 2016, p. 405) and it has been adopted in a scholarly research (Geldes et al., 2017; Lee, Lee \& Garrett, 2019; Mothe \& Nguyen, 2012; Pino, Felzensztein, Zwerg-Villegas, \& AriasBolzmann, 2016). This definition also aligns with the measurement used in the Community Innovation Survey which has been subjected to extensive testing across numerous countries. The Community Innovation Survey is a survey of innovation activity that is conducted by European Union countries and others. It is noted that the Oslo Manual (OECD, 2018) was recently updated but these definitions are yet to be incorporated within academic and policy literatures. 
Table 1 Descriptions of Marketing Innovation

\begin{tabular}{|c|c|}
\hline Description & References \\
\hline $\begin{array}{l}\text { Development of new services, new } \\
\text { price-setting strategy, new } \\
\text { advertising promotions, new } \\
\text { distribution channels and } \\
\text { marketing information systems }\end{array}$ & Gupta et al., (2016, p. 5673) \\
\hline $\begin{array}{l}\text { New pricing methods, new } \\
\text { distribution methods, new sales } \\
\text { approaches, leasing arrangements, } \\
\text { and entering a new market }\end{array}$ & Weerawardena (2003, p. 34) \\
\hline $\begin{array}{l}\text { Firm's ability to develop new } \\
\text { solutions to satisfy customers' } \\
\text { current and future needs }\end{array}$ & Ngo \& O’Cass (2012, p. 865); O’Dwyer et al. (2009b) \\
\hline $\begin{array}{l}\text { Alteration of marketing mix (4Ps); } \\
\text { Improvements in product design, } \\
\text { placement, promotion or pricing }\end{array}$ & $\begin{array}{l}\text { Naidoo (2010, p. 56) ; Shergill \& Nargundkar (2005); } \\
\text { Tsourvakas et al., (2016); Kafetzopoulos \& Psomas } \\
\text { (2016) }\end{array}$ \\
\hline $\begin{array}{l}\text { Implementation of a new } \\
\text { marketing method involving } \\
\text { significant changes in product } \\
\text { design or packaging, product } \\
\text { placement, product promotion or } \\
\text { pricing (Oslo Manual) }\end{array}$ & $\begin{array}{l}\text { OECD (2005, p. 45); Bartoloni \& Baussola (2015); } \\
\text { Camisén \& Villar-López (2011); Geldes et al. (2017); } \\
\text { Medrano \& Olarte-Pascual (2016); Wong (2013); } \\
\text { Cruz-Ros, Garzón, \& Mas-Tur, (2017); Bortoluzzi et } \\
\text { al., (2018) ; Ramirez, Parra-Requena, Ruiz-Ortega, } \\
\text { Garcia-Villaverde (2018) }\end{array}$ \\
\hline $\begin{array}{l}\text { New techniques and tools to } \\
\text { improve sales }\end{array}$ & Fuentes-Blasco et al., (2017) \\
\hline $\begin{array}{l}\text { Adapting the product to customers' } \\
\text { needs and innovate in customer } \\
\text { management }\end{array}$ & Sánchez-Gutiérrez et al., (2019, p. 619) \\
\hline $\begin{array}{l}\text { Firms ability to approach the } \\
\text { market, effectively use the } \\
\text { channels of communication, and } \\
\text { deliver product and service to } \\
\text { capture potential or existing } \\
\text { customers }\end{array}$ & Lee et al., (2019, p. 509) \\
\hline
\end{tabular}




\section{METHODOLOGY}

Given the diversity around the descriptions of marketing innovation and the fragmented use and measurement of the concept, we follow a "systematic review process” (Transfield, Denyer, \& Smart, 2003) to identify key scientific contributions to marketing innovation. The main difference between a systematic review and a traditional narrative review is "the former uses a rigorous, replicable, scientific and transparent process.” (Becheikh, Landry, \& Amara, 2006, p. 645). A systematic review is, however, different from a meta-analysis in the sense that it does not use statistical and econometric procedures for synthesising findings and analysing data. Our systematic review process follows three steps: data collection, data analysis, and reporting of the results (Figure 1). 
Figure 1 Key steps of the systematic review process ${ }^{1}$

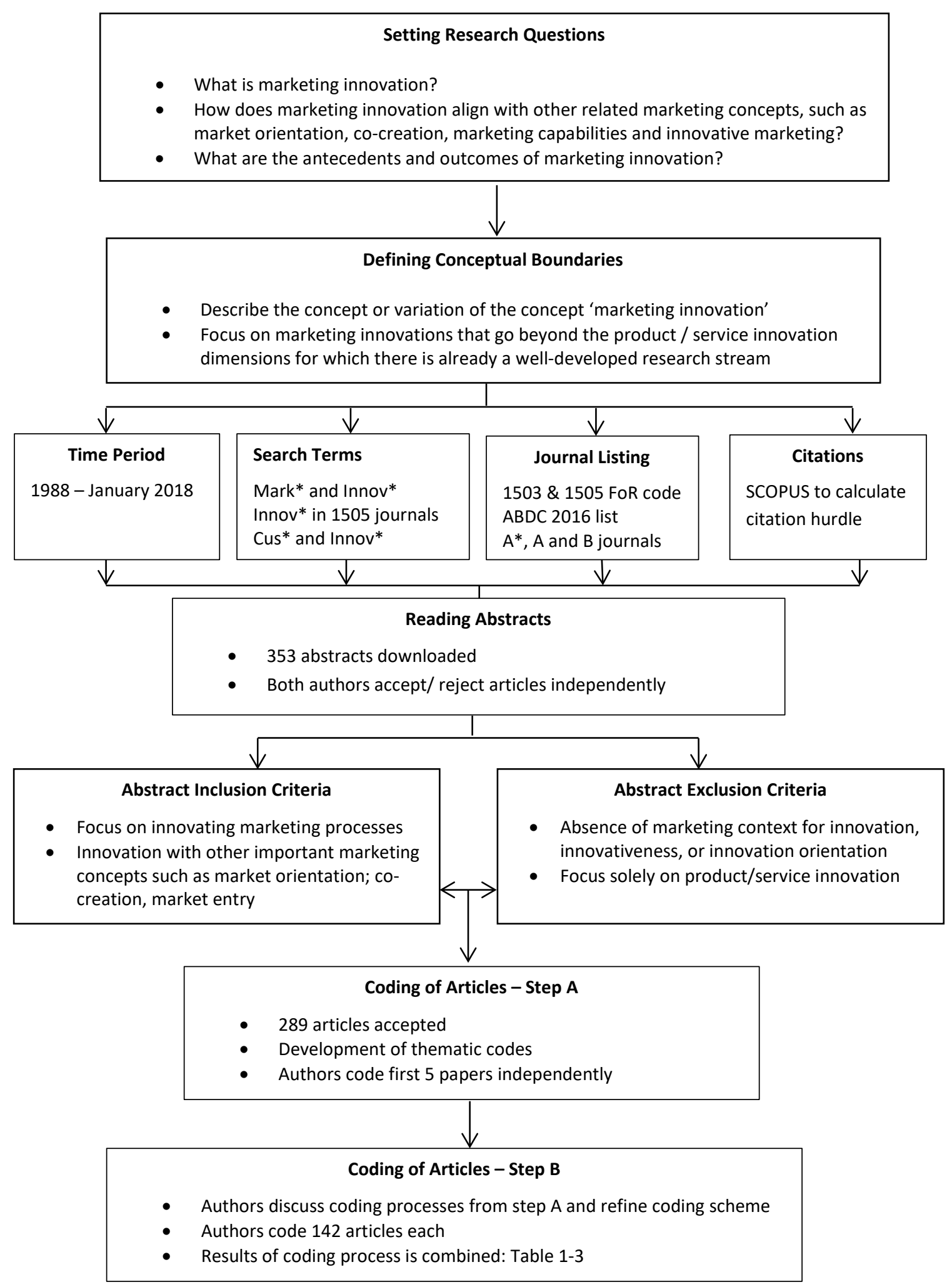

${ }^{1}$ Innov* uses Innov as the stem search term and encompasses innovation, innovativeness, innovator etc. Similarly for the other search terms. 


\section{Data Collection}

A systematic review requires researchers to make decisions around bounding the search criteria for relevant articles. In this review five decisions were made and are listed below.

An initial ad hoc reading on the use of the term 'marketing innovation' indicated a number of variations around the term, with three different searches conducted. In a first search, articles that include mark* and innov* within the title, abstract or keywords were included in the search of management and marketing journals (FoR 1503 \& 1505). Mark* captures marketing, market, and marketers, and Innov* captures innovation, innovative, innovators, innovativeness. In a second search, recognising the fact that innovative marketing encompasses a variety of activities such as packaging, distribution, promotion and so on, we included all articles with Innov* within the title, abstract or keywords in marketing journals (FoR 1505 only).. Also, recognising that customers are an important component within marketing innovation a third search, in management and marketing journals, was conducted that included cus* and innov* within the title, abstract or keywords. The output from these successive searches was included in our database of articles.

Second, we determined the temporal boundaries for the review. Although innovation in marketing has been discussed by various authors for several decades (Drucker, 1954; Rogers, 1962), we noticed research in this field gained momentum in the mid-1980s. Consequently, we focused our attention over the past three decades and our time period was concerned with articles published from 1988 until August 2019.

Third, to ensure that our articles focused on marketing innovation topics, rather than innovation from a purely engineering perspective, the search was bounded by the Australian Research Council four digit FoR codes. FoR codes included were 1503: Business and Management and 
1505: Marketing. 1503 includes journals covering technology and innovation management and could include research on 'marketing innovation'.

Fourth, while it is recognised that articles impacting theoretical developments don't always emerge from top tier journals, a list of relevant peer reviewed journals needed to be developed. We used the 2016 Australian Business Deans Council (ABDC) Journal Quality List ${ }^{2}$ as a starting point for assessing publication quality and included all journals ranked as A*, A and B. This list encompasses a broad number of journals that cover innovation and marketing topics and includes a greater range of journals than others such as the Chartered Association of Business Schools (ABS) ${ }^{3}$ and the Financial Times Top 50.

Lastly, citations were used to prioritise articles that impacted the development of the marketing innovation concept. Articles were incorporated into the initial database that had citations, gathered via SCOPUS, equal to or greater than 40 for the 1988-2007 period, 30 for the 20082010 period, 20 for the 2011-2012 period, and 10 for the 2013-2014 period. No citation hurdle was required for articles published since 2015.

\section{Data Analysis}

The data collection process yielded 353 articles, whose abstracts were downloaded. To ensure each article focused on marketing innovation, the two authors then read the abstracts to screen the articles accordingly. As a result of this screening process, 289 articles were selected for the final analysis.

Thematic codes were then developed to analyse these 289 full articles and include: type of paper (empirical vs. conceptual), theoretical anchor (resource-based view/capabilities, market/customer orientation, diffusion of innovation, industrial network approach/relationship

\footnotetext{
${ }^{2}$ http://www.abdc.edu.au/master-journal-list.php

${ }^{3}$ https://charteredabs.org/academic-journal-guide-2018/
} 
marketing, co-creation, service-dominant logic), level of analysis (inter-organisational, firm, customer), method (survey, case, interview, other qualitative and quantitative methods), and country for data collection (North America, Europe, Asia, Oceania, rest of the world). The descriptive codes were developed from Tranfield et al., (2003) who included similar codes to describe the sample articles.

Codes for the focal innovation concepts were firstly developed from the marketing innovation definition. However, on reading the article abstracts, it became clear that some articles focused on organisational aspects and brand innovation which did not align with the original definition but were nevertheless included in the focal innovation concept. Brand innovation was conceptualised as a part of the offering and novelty of consumer experience. For example Boisvert \& Ashill, (2011, p. 518) define service brand innovativeness as "as the extent to which intangible offerings, actions, and reactions are perceived as novel by customers” thus highlighting novelty in not just the new service offering but also including the service experience. Another code was developed to capture research outcomes focusing on the organisational aspects relating to the structure, role of external actors, administrative processes, and capability development driving marketing innovation.

The two authors independently read and coded the first five articles and then discussed their results and the criteria used. Once agreement around the coding criteria and process was achieved, the rest of the articles were divided between both authors for further coding. The results detailing the level of analysis, method, and geographic focus are shown in Table 2. Numerous methodologies were used within the empirical research where some methods were only used occasionally and grouped into other 'quantitative methods' (e.g. Agent Based Modelling - Günther, Stummer, Wakolbinger, \& Wildpaner, (2011)) and other 'qualitative methods' (e.g. historical analysis - Sandgren (2016)). Within geographic focus articles coded to region (e.g. Asia) incorporated data collection from a country in the region; 'multiple 
countries' focused on cross-cultural analysis with data collected from multiple countries and 'rest of the world' included regions which were not previously covered (e.g. Africa - Onyas \& Ryan (2015) \& Chile - Geldes et al., (2017)).

Table 2 Level of analysis, type, method and geographic focus of the paper in the sample

\begin{tabular}{|c|c|c|}
\hline & Number & Selected Recent References \\
\hline \multicolumn{3}{|l|}{ Level of Analysis } \\
\hline Firm & 193 & $\begin{array}{l}\text { Rubera \& Kirca (2017); Santos-Vijande et al. (2016); De Luca } \\
\text { \& Atuahene-Gima (2007); Ernst et al. (2015); Dotzel et al. ( } \\
\text { 2013); Story et al. (2009) }\end{array}$ \\
\hline Consumer/customer & 64 & $\begin{array}{l}\text { Zhang \& Hou (2017); Claudy et al. (2015); Persaud \& Azhar, } \\
\text { (2012); Boisvert \& Ashill (2011); Anselmsson \& Johansson } \\
\text { (2009) }\end{array}$ \\
\hline Inter-organisational & 25 & $\begin{array}{l}\text { D'Antone et al. (2017); Burki \& Dahlstrom (2017); Purchase et } \\
\text { al. (2016); Perks \& Moxey (2011); Rampersad et al. (2010); }\end{array}$ \\
\hline \multicolumn{3}{|r|}{ (- } \\
\hline Empirical & 258 & $\begin{array}{l}\text { Rosenzweig (2017); Sheng (2017); Tabeau et al. (2017); } \\
\text { Vicente et al. (2015); Sok \& O'Cass (2015); Storbacka \& } \\
\text { Nenonen (2015); Tsou, Chen \& Liao (2014); }\end{array}$ \\
\hline Conceptual & 31 & $\begin{array}{l}\text { Varadarajan (2017); Brexendorf et al. (2015Reinartz et al. } \\
\text { (2011); Shankar etal., (2011) ; O'Dwyer, Gilmore \& Carson } \\
\text { (2009a) }\end{array}$ \\
\hline \multicolumn{3}{|r|}{ (2) } \\
\hline Survey & 177 & $\begin{array}{l}\text { Dotzel et al. (2013); Zhang \& Hou (2017); Fernandes \& } \\
\text { Remelhe (2016) ; Gupta et al. (2016) ; Ngo \& O'Cass (2012); } \\
\text { Shergill \& Nargundkar (2005) }\end{array}$ \\
\hline Case study & 42 & $\begin{array}{l}\text { Rosenzweig (2017); Laursen \& Andersen (2016); Tsourvakas et } \\
\text { al. (2016); Beverland (2005) }\end{array}$ \\
\hline Interviews & 12 & $\begin{array}{l}\text { Puhakka et al. (2018); Sharma, al. (2014); Chimhundu et al. } \\
\text { (2010); O'Dwyer, Gilmore \& Carson (2009b) }\end{array}$ \\
\hline Other-quantitative & 19 & $\begin{array}{l}\text { Lee \& Johnson (2017); Bartoloni \& Baussola (2015 Medrano \& } \\
\text { Olarte-Pascual (2016); Tyagi et al. (2015); Choi et al., (2010); } \\
\text { Günther et al., (2011) }\end{array}$ \\
\hline Other-qualitative & 12 & $\begin{array}{l}\text { Onyas \& Ryan (2015); Verganti \& Öberg (2013); Chiesa and } \\
\text { Frattini (2011) }\end{array}$ \\
\hline \multicolumn{3}{|l|}{ Geographic focus } \\
\hline Asia & 45 & $\begin{array}{l}\text { Park et al. (2010); Sheng (2017); Hsieh \& Tsai (2007); Lee et } \\
\text { al., (2019) }\end{array}$ \\
\hline Europe & 87 & $\begin{array}{l}\text { Puhakka et al. (2018); Burki \& Dahlstrom (2017); } \\
\text { Medrano \& Olarte-Pascual (2016); Berghman et al. (2012); }\end{array}$ \\
\hline North America & 56 & $\begin{array}{l}\text { Yeniyurt, Henke \& Yalcinkaya (2014); Boisvert \& Ashill } \\
\text { (2011); Veryzer (2005)’ Mugge \& Schoormans (2012) }\end{array}$ \\
\hline Oceania & 15 & $\begin{array}{l}\text { Purchase, Kum, \& Olaru (2016); Weerawardena (2003); O'Cass } \\
\text { \& Carlson (2012); O'Cass \& Weerawardena (2009) }\end{array}$ \\
\hline Multiple Countries & 41 & $\begin{array}{l}\text { Lee \& Johnson (2017); Vicente et al. (2015); Beverland et al., } \\
\text { (2010); Sandgren (2016); Yan et a., (2016) }\end{array}$ \\
\hline Rest of the world & 9 & $\begin{array}{l}\text { Jürgensen \& Guesalaga (2018); Geldes et al. (2017) ; Onyas \& } \\
\text { Ryan (2015) ; Pino et al., (2016) }\end{array}$ \\
\hline
\end{tabular}




\section{Sample Description}

The articles included in our sample mainly focus on analysing concepts at the firm level (193), rather than the consumer/customer level (64). It should be noted that when articles focus on the consumer or customer level (e.g. Jürgensen \& Guesalaga, 2018; Mugge \& Dahl, 2013), they often develop their discussion and implications on how marketing practitioners can incorporate this information to improve their marketing performance, rather than how the customers'/ consumers' themselves may benefit from this research. Therefore, there is a strong focus towards the impact of research on firms, even when the level of analysis is the customer/ consumer.

Empirical research articles (258), mainly use primary data techniques such as survey techniques (177) are strongly represented in our sample. With a small number of exceptions focusing on secondary data (e.g. Medrano \& Olarte-Pascual, 2016; Bartoloni \& Baussola, 2016; Camisón \& Villar-López, 2011; Geldes, Felzensztein \& Palacios-Fenech, 2017). Interestingly, the geographic focus is not just concentrated on western developed economies, e.g. Europe (87) and North America (45), but also has a strong Asian (45) focus. Research focusing on South America, Africa, the Middle-East and Oceania is scarcer.

\section{RESULTS}

\section{Theoretical Anchors}

First, we developed a list of the journals in which the 353 articles in our sample have been published. As shown in Table 3, all major marketing journals are represented in this list, with Industrial Marketing Management (68 articles), the Journal of the Academy of Marketing Science (34 articles), and the Journal of Product Innovation Management (21 articles) topping the list. 
Table 3 Overview of the articles included in the review with journals and main theoretical anchors

\begin{tabular}{|c|c|c|c|c|c|c|c|}
\hline Journal & $\begin{array}{c}\text { Number of } \\
\text { Articles }\end{array}$ & $\begin{array}{l}\text { Resource- } \\
\text { based view / } \\
\text { Perspective }\end{array}$ & $\begin{array}{c}\text { Customer/ } \\
\text { Market } \\
\text { Orientation } \\
\text { Perspective } \\
\end{array}$ & $\begin{array}{c}\text { Diffusion } \\
\text { of } \\
\text { Innovation } \\
\end{array}$ & $\begin{array}{c}\text { Industrial } \\
\text { network / } \\
\text { Relationship } \\
\text { Marketing } \\
\end{array}$ & $\begin{array}{l}\text { Co-creation } \\
\text { Approaches }\end{array}$ & $\begin{array}{c}\text { Service- } \\
\text { Dominant } \\
\text { Logic } \\
\end{array}$ \\
\hline Industrial Marketing Management & 68 & 28 & 7 & 3 & 6 & 4 & \\
\hline Journal of the Academy of Marketing Science & 34 & 4 & 6 & 3 & 1 & 2 & 3 \\
\hline Journal of Product Innovation Management & 21 & 6 & 2 & 2 & 1 & 1 & \\
\hline Journal of Business \& Industrial Marketing & 16 & 4 & 2 & 2 & 1 & 3 & 1 \\
\hline Journal of Strategic Marketing & 12 & 7 & 2 & & & 1 & 1 \\
\hline European Journal of Marketing & 11 & 1 & 2 & 1 & & & \\
\hline Journal of Consumer Marketing & 8 & & & 2 & & & \\
\hline Australasian Marketing Journal & 7 & 2 & 1 & & 1 & & \\
\hline International Marketing Review & 9 & 2 & 2 & & 1 & & \\
\hline Journal of Services Marketing & 6 & 2 & 1 & & & & \\
\hline Journal of Marketing & 9 & 2 & 1 & & & & \\
\hline International Journal of Bank Marketing & 4 & 1 & 1 & 1 & & & \\
\hline International Journal of Consumer Studies & 4 & & & 4 & & & \\
\hline Journal of Marketing Management & 3 & 2 & & & & & \\
\hline Other & 77 & 8 & 10 & 10 & 4 & 4 & 0 \\
\hline Total & 289 & 67 & 37 & 28 & 15 & 15 & 5 \\
\hline
\end{tabular}

Note: This table outlines the six most popular theoretical approaches used the 184 articles in our sample 
In terms of theoretical anchors, the resource-based view (RBV) has been the favoured analysis perspective to study marketing innovation (67 articles). This perspective suggests that each organisation has a distinctive set of resources and capabilities, and some capabilities will have greater impact on financial performance than the others (Weerawardena, 2003). Scholars studying marketing innovation have examined the effects of resources on both general business performance (Dotzel, Shankar, \& Berry, 2013) and innovation-related performance variables such as incremental vs. radical innovation (Atuahene-Gima, 2005) or new product success (Harmancioglu, Droge, \& Calantone, 2009; Li \& Calantone, 1998). Diverse market-based resources appear in this domain, including marketing capabilities (Dutta, Narasimhan, \& Rajiv, 1999; Matthyssens, Vandenbempt, \& Berghman, 2006), market knowledge competence (Li \& Calantone, 1998; Rosenzweig, 2017; Zhang \& Zhu, 2016), technology and R\&D capabilities (Eggert, Thiesbrummel, \& Deutscher, 2015; Hsieh \& Tsai, 2007), learning capabilities (Berghman, Matthyssens, \& Vandenbempt, 2012; Camisón \& Villar-López, 2011; Sok, O’Cass, \& Sok, 2013), and organisational ambidexterity (Sok, \& O'Cass, 2015; Sheng, 2017).

The market and customer orientation perspective is the second most prevalent theoretical anchor in our sample (37 articles). Market orientation captures the capacity of firms to address both expressed and latent needs of customers (Slater \& Narver, 1999). Similar to the RBV perspective, most of the literature on market orientation demonstrates a positive and direct relationship with performance (Narver \& Slater, 1999; Agarwal, Krishna Erramilli, \& Dev, 2003). However, several scholars have suggested that innovation is a "missing link" between market orientation and organisational performance (Han, Kim, \& Srivastava, 1998). Accordingly, several studies have examined the impact of market orientation on a variety of innovation dimensions, such as commitment to innovation (Slater \& Narver, 1994), marketing innovation (Naidoo, 2010), and innovativeness (Perks \& Moxey, 2011; Vázquez, Santos, \& Alvarez, 2001), which in turn affect business performance. 
A third theoretical framework is the diffusion of innovations theory (Rogers, 1962; Bass 1969). This perspective shifts the focus of analysis from the firm to the customer and the consumer, and takes a measure of the time fromintroduction until adoption as an indicator of consumer innovativeness. Researchers have typically used time-of-adoption to assign consumers to the adopter categories (Fell, Hansen, \& Becker, 2003; Heiskanen \& Matschoss, 2016) and examine the consumer willingness to purchase new products (Claudy et al., 2015; Puhakka, Valve, \& Sinkkonen, 2018), sometimes combined with the study of personal traits (Park, Yu, \& Zhou, 2010; Jürgensen \& Guesalaga, 2018). This theoretical perspective also emphasises the "role individual innovativeness plays in shaping technology acceptance” (Chiu, Fang, \& Tseng, 2010, p.454) which in turn influences the implementation of marketing innovations, especially for new design (Lee \& Johnson, 2017), online channels (Eriksson, Kerem, \& Nilsson, 2008; Laukkanen, Sinkkonen, Kivijärvi, \& Laukkanen, 2007), and new brands (Boyd \& Mason, 1999).

We identified three other theoretical anchors of lesser importance: industrial network / relationship marketing, co-creation perspective, and service-dominant logic, which we do not review here in detail. In addition, co-creation and service-dominant logic will be discussed in the section on innovation as a process.

\section{The Object of Marketing Innovation}

What is the focus of marketing innovation in the literature? In this section, we examine marketing innovation along the coded innovation focal aspects presented in Table 4 . All articles considered in this review include some elements of marketing strategy and practice, although the focal innovation can sometime relate to the product or service. As shown in Table 4, the vast majority of articles draw on technological innovations (product and service innovations). A series of 37 articles cover a combination of organisational and marketing innovations and 41 
other articles examine innovation via changes to multiple marketing mix categories (e.g. Medrano \& Olarte-Pascual, 2016; O’Dwyer, Gilmore, \& Carson 2009b; Shergill \& Nargundkar, 2005). A smaller number of articles consider a specialised dimension of marketing innovation, such as pricing, and therefore contribute to our understanding of marketing innovation through these specialised dimensions. Therefore, these were included within our analysis, a summary of our results is presented in Figure 2. Figure 2 illustrates new product/ service as the main research focus, encircled by marketing innovation constructs. Thus, aligning with Garcia and Calantone (2002) that marketing innovation is necessary in order for radically new products/ services to be successful. 
Table 4 Focal marketing innovation aspects of the articles in the sample

\begin{tabular}{|c|c|c|}
\hline $\begin{array}{l}\text { Focal innovation aspect (n } \\
\text { articles) }\end{array}$ & Exemplar code for categorisation & Selected recent references \\
\hline \multicolumn{3}{|l|}{ Technological } \\
\hline New product (63) & $\begin{array}{l}\text { New product development coupled with } \\
\text { marketing strategies; change of product functions } \\
\text { or characteristics }\end{array}$ & $\begin{array}{l}\text { Atuahene-Gima (2005) ; Griffin et al. (2013); Sok \& } \\
\text { O'Cass (2015) ; Zhou et al., (2005) ; Thornhill (2006) }\end{array}$ \\
\hline New service (31) & Services with new service functions or use & $\begin{array}{l}\text { Wang et al. (2016); Skålénet al. (2014); Spring \& } \\
\text { Araujo (2013) }\end{array}$ \\
\hline \multicolumn{3}{|l|}{ Non-technological } \\
\hline $\begin{array}{l}\text { Organisational aspects of } \\
\text { marketing innovation (37) }\end{array}$ & $\begin{array}{l}\text { Capabilities, strategy, structure and procedures } \\
\text { associated with marketing innovation processes. }\end{array}$ & $\begin{array}{l}\text { Berghman et al. (2012Geldes et al. (2017); Mariadoss } \\
\text { et al. (2011); Weerawardena et al. (2014); Wei \& } \\
\text { Wang (2011) }\end{array}$ \\
\hline Design (10) & $\begin{array}{l}\text { Changes to the design and packaging of product } \\
\text { without changing function or use; change in the } \\
\text { form, appearance or taste of the product }\end{array}$ & $\begin{array}{l}\text { Homburg et al. (2015); Lee \& Johnson (2017); Page } \\
\text { \& Herr (2002) }\end{array}$ \\
\hline Brand (9) & $\begin{array}{l}\text { Changes to the brand of a product/service } \\
\text { without changing its function or use; new brand } \\
\text { symbol }\end{array}$ & $\begin{array}{l}\text { Boyd \& Mason (1999); Boisvert \& Ashill (2011); } \\
\text { Brexendorf et al. (2015); Nguyen et al. (2015); Aaker } \\
\text { (2007); Keller (2012) }\end{array}$ \\
\hline Pricing (6) & $\begin{array}{l}\text { New methods for pricing setting of products / } \\
\text { services; e.g. dynamic pricing, individualised } \\
\text { pricing, flat fee, or Pay What You Want }\end{array}$ & $\begin{array}{l}\text { Schulz et al. (2015); Balan (2014); Hinterhuber \& } \\
\text { Liozu (2014); Kim et al. (2009) }\end{array}$ \\
\hline Distribution (11) & $\begin{array}{l}\text { New distribution channels; introduction of } \\
\text { franchising system, direct selling, exclusive } \\
\text { retailing, omni-channel, pickup store }\end{array}$ & $\begin{array}{l}\text { Hagberg et al. (2016); Verhoef et al. (2015); Krafft et } \\
\text { al. (2015); Hulthén \& Gadde (2007); Homburg et al., } \\
\text { (2015) }\end{array}$ \\
\hline Promotion (11) & $\begin{array}{l}\text { New concepts for promoting a product/service, } \\
\text { both B2C and B2B; integrated marketing } \\
\text { communication; social media; mobile marketing }\end{array}$ & $\begin{array}{l}\text { Leenders et al. (2017); Yeniyurt et al. (2014); } \\
\text { Mangold \& Faulds (2009); Hariharan et al., (2015) }\end{array}$ \\
\hline $\begin{array}{l}\text { Marketing Innovation as a } \\
\text { signle vs multiple construct } \\
\text { (41) }\end{array}$ & $\begin{array}{l}\text { Alteration of multiple aspects of the marketing } \\
\text { mix, process or tactic }\end{array}$ & $\begin{array}{l}\text { Rubera \& Kirca (2017); Medrano \& Olarte-Pascual, } \\
\text { (2016); O’Dwyer et al. (2009b) }\end{array}$ \\
\hline
\end{tabular}




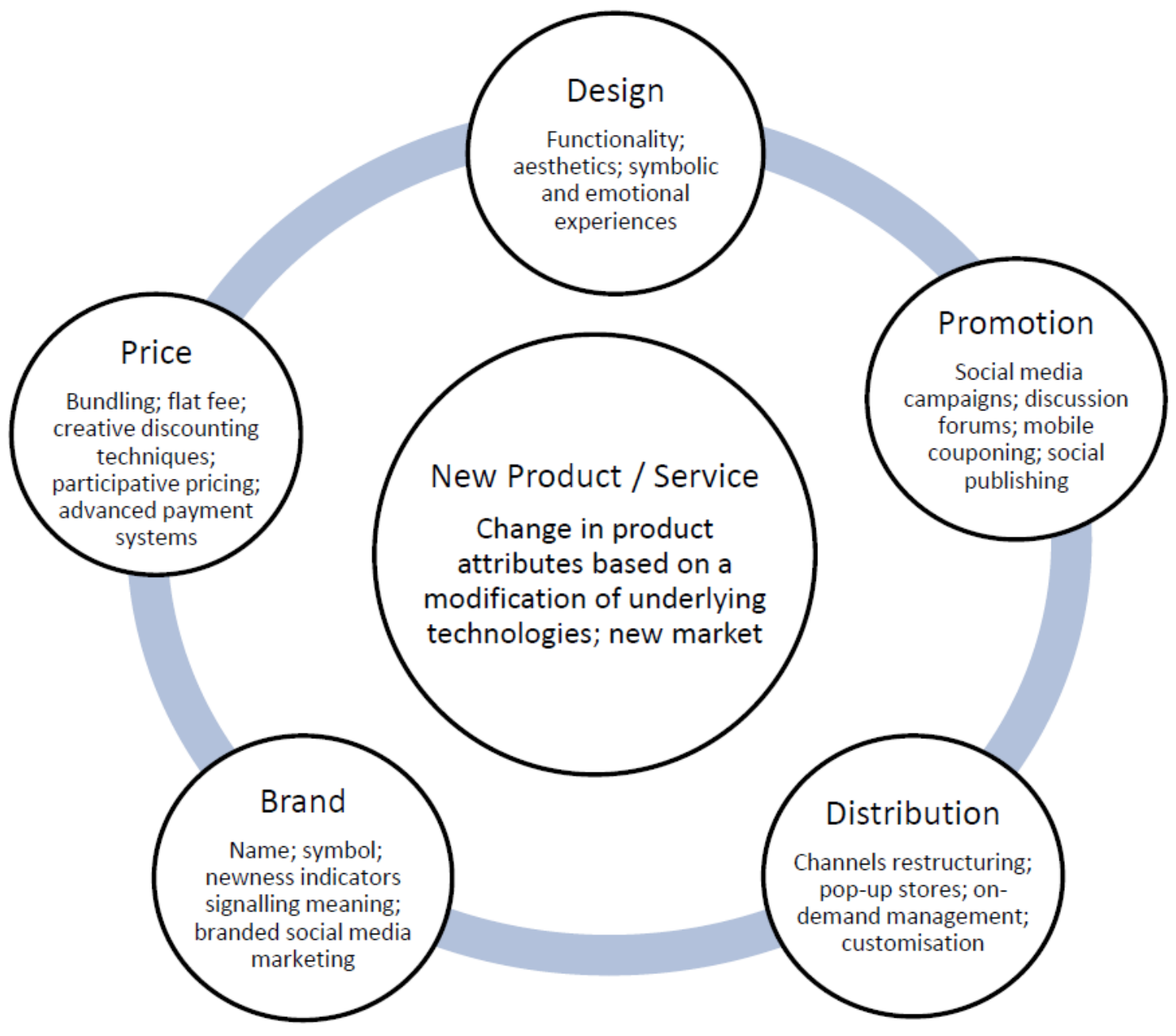

Technological innovation: New Product or New Service

A large number of articles adopt a technological innovation perspective to examine new product development (63 articles) or service development (31 articles) development. This view defines product innovation as a change in product attributes based on a modification of underlying technologies (Chandy \& Tellis, 2000). Although our review focuses primarily on innovation beyond conventional product and service development, we considered these articles in our sample because they include some elements of marketing innovation. Indeed, it is often 
difficult to disentangle marketing strategies and practices from new product development activities.

For example, in their study of new product development Ernst, Kahle, Dubiel, Prabhu and Subramaniam (2015) indicate that an 'affordable value innovation', pricing strategy, is important for new products in emerging countries. Another example is Reydet and Carsana’s (2017) study on the development of new banking services and the positive influence that both digital and traditional channels have on customer commitment.

Sometimes the development and commercialisation of new products and services create new markets altogether. Zhou, Yim and Tse (2005) describe market-based innovation as "creating a set of fringe, and usually new, customer values for emerging markets” (p. 43). Recent attention to the active production of markets suggests that they are ongoing processes rather than stable entities. Moving beyond the technological dimension of new products, marketing innovation, therefore, can lead to a change of existing market structure, an alteration of market behaviour, and new arrangement between market agents. (Kjellberg, Azimont, \& Reid, 2015, p. 4)

Non-technological Innovation: Organisational Aspects of Marketing Innovation

Research focusing on 'organisational aspects' covers three broad themes: (1) marketing practices and capabilities associated with innovation processes, (2) role of external actors in the organisation's innovation processes, and (3) role of internal actors on innovation development. Each of these themes are discussed in more detail below.

When considering how marketing practices are associated with innovation processes, most articles focused on (marketing) strategies, capabilities, skills and activities. Innovation was conceptualised as marketing innovation or commonly considered as another innovation 
concept of which marketing innovation was a component of the construct (i.e. organisational innovation). For example organisational innovation intensity was measured to capture product, process, managerial and marketing innovations (O’Cass \& Weerawardena, 2009; Weerawardena, 2003), thus incorporating marketing innovation within an overarching innovation construct. While most scholars found that marketing practices had a positive impact on innovation improvement, there were some contradictory findings particularly in relation to cross-functional teams. For example whether or not to include marketing capabilities for product design and development was inconclusive in the UK (Love \& Roper, 2009); marketing capabilities do not improve the effectiveness of innovation projects (Brettel, Heinemann, Engelen \& Neubauer, 2011), and different aspects of customer information learning may limit innovativeness in organisations (Mena \& Chabowski, 2015).

A second stream of research focused on the role of external actors (e.g. customers and suppliers) in the organisation's innovation processes and whether they improve innovation performance. The governance of these external relationships is an important organisational function. The influence of customers within new product or service development has been considered from two perspectives: customers driving innovation development (e.g. Hyysalo, Repo, Timonen, Hakkarainen \& Heiskanen, 2016) or organisations developing strategies to include different customer segments purposely (e.g. Mahr, Lievens \& Blazevic, 2014; Burki \& Dahlstrom, 2017). This research stream has benefited from co-creation approaches (e.g. Fang, Palmatier \& Evans, 2008) and service-dominant logic concepts (e.g. Michel, Brown, \& Gallan, 2008). The role of suppliers, while not a strong research theme, was found to improve incremental innovation activities (Song \& Thieme, 2009). Therefore, external actors influence marketing innovations undertaken within an organisation.

A third stream revolves around the influence of internal actors on the development and implementation of marketing innovations. Of particular importance was the role of frontline 
employee participation, especially in service contexts. Studies consider the complex role of motivation in engaging employee participation (Cadwallader, Jarvis, Bitner, \& Ostrom, 2010), collaboration with front line employees along the new service development process (SantosVijande, López-Sánchez, \& Rudd, 2016), and employees’ innovation-oriented values and norms (Stock, Six, \& Zacharias, 2013) to provide new, unique service experience. Sales people also have a role in recognising and developing new innovative opportunities to develop customer value (Bonney \& Williams, 2009). Management also influences the development and implementation of marketing innovations, where compositional factors such as firm size can limit the uptake of marketing innovations (Bengtsson, Botter \& Vanyushyn, 2007). Wong (2013) found that while human resources positively influences marketing innovation, the administrative process did not. While marketing innovations may be facilitated within the marketing department, other departments (e.g. human resources, sales) or divisions will be involved with the development and implementation of these programs.

\section{Design}

There is broad agreement in the marketing innovation literature that design captures the traditional product functionality (i.e., product features and related benefits) and aesthetics (i.e., product's sensorial characteristics), but also product meaning (i.e., product associations in customers’ minds) (Bloch 1995; Homburg, Schwemmle, \& Kuehnl, 2015; Kim, Kim, \& Choi, 2017). Therefore, design innovation is defined "not only in terms of product's appearance, but also in terms of newness in the emotions that products evoke and the way they enable customers to express their identity.” (Tabeau, Gemser, Hultink, \& Wijnberg, 2017, p. 205). The firm, though marketing and communication programs, can significantly influence customers' perceptions of product design and create meaning around the symbolic and emotional experience of a product that is shared by its customers (Karjalainen \& Snelders, 2010; Srinivasan, Lilien, Rangaswamy, Pingtore, \& Seldin, 2012). Many firms therefore aim to 
develop an inimitable, distinctive and iconic design for their products or product packaging that is closely aligned with to their brand identity.

During a new product launch, product design choices along parameters related to material, shape, proportions, and marketing communication can greatly influence consumers' cognitive and emotional responses to the innovation (Veryzer, 2005; Mugge \& Schoormans, 2012). However, these important design choices are different to technological design, which are more commonly studied by innovation researchers. For example, product design innovation can influence a product's novelty by emphasising or hiding different facts of the technology that the innovation introduces or it can provide visual cues that can be interpreted by consumers and create meaning (Rindova \& Petkova, 2007). In addition design and the underlying technological change interact in determining how consumers assess the value and learning costs of innovation, and thus the likelihood that consumers will adopt it (Mugge \& Dahl, 2013).

In the same vein, Kim et al. (2017) show that design innovation helps improve perceived value, which also plays an important role in consumers’ buying decisions. Furthermore, consumers may associate a novel design with greater performance quality (Mugge \& Schoormans, 2012). However, Mugge \& Dahl (2013) suggest that a high level of design newness may in some cases be detrimental. Specifically, in the case of radical innovations which have functional attributes that are very different from those of existing products, a low level of design newness can provide a frame of reference, thus reducing the perceived learning costs and increasing product adoption.

\section{Brand}

Our review suggests that brands are an integral part of marketing innovation. Brand, as a name, term, symbol or any other feature, offer cues that consumers can use to evaluate product performance (Page \& Herr, 2002). Brands give new products and services meaning and 
facilitate their launch. They allow ownership of an innovation, add credibility and legitimacy enhance visibility, and support communication (Boisvert \& Ashill, 2011).

More often than not, brand innovation tends to be intertwined with new product introduction. For example, Bertini, Gourville and Ofek (2011, p. 36) note that “Consumers don’t necessarily read specs to learn about new features, but they’ll always notice a new name.” Many new products are often introduced as brand extensions because of the advantages such a branding strategy can afford. Consumers can form expectations about whether they think that they will like a new product based in part on what they know about its parent brand (Keller, 2012). Marketers can use the core brand name and add a series of newness indicators that convey the next generation such as a number (e.g., iPhone 11), a date (PowerPoint 2016), or a superlative (e.g., Boeing 737 Max or Mercedes SL for Sport Leicht) (Brexendorf et al., 2015). Branding strategy for new production generation essentially depends on the degree to which a firm wants to signal novelty and innovation (Bertini et al., 2011). If a brand name extension is used, consumers expect further improvements of existing features in the new product over its predecessor. Conversely, with brand name change, customers expect radically new features.

However, many scholars acknowledge that brand innovations encompass more than simply putting a name and logo on a new product, but rather require developing a coherent strategy, supported by brand-building programs (Aaker, 2007; Beverland, Napoli, Farrelly, 2010). Specifically, this entails developing a combination of product and communication strategies which generates strong knowledge, functionality and emotions amongst customers. As Keller (2012, p.187) remarks: "Successful brands ensure that their products and services are made, sold, advertised and discussed in a way that profoundly affects consumers in the head and the heart.” Brand strategy therefore must align with other aspects of marketing such as product and design to communicate the core value of the brand. This can happen through acts of "semantic 
transformation" whereby novel brand descriptions are transformed in value-based design features which generate the intended meaning of products (Karjalainen \& Snelders, 2010).

Marketing managers increasingly rely on social media to encourage ongoing interaction between consumers and the brand, and in this process, to create emotional connections. “Branded social media marketing” (Ashley \& Tuten, 2015) helps maintain customer engagement and increase the functional and experiential appeal of the brand. Thus, an effective communication of the brand is an essential part of marketing innovation. Our review suggests that even retailer brands and seemingly “me-too” products can score relatively well in terms of innovation because many retailers have managed to position their brands more successfully than market leaders, for example within areas such as corporate social responsibility (Anselmsson and Johansson, 2009).

\section{Pricing}

Compared to the other marketing mix components, price seems to be a less likely area of innovation. However, our review reveals that companies worldwide are experimenting with new pricing methods in an attempt to capture the attention of customers and forge new relationships with them. Hinterhuber and Liozu (2014, p. 413) note that “Innovation in pricing brings new-to-the-industry approaches to pricing strategies, to pricing tactics, and to the organisation of pricing with the objective of increasing customer satisfaction and company profits.”

Most of the research conducted on innovative pricing strategies focuses on B2C rather than B2B context (Chen \& Zhang, 2015). A number of possible avenues for innovation in B2C pricing, include bundling (selling two or more products or services as a package), individualised pricing (charging different prices for identical products or services based on individual customer data), flat fee (allowing unlimited consumption for a fixed fee), creative 
discounting techniques (e.g., steadily decreasing discounts whereby discounts are gradually phased out), and participative pricing mechanisms (e.g., “name your own price”) (Balan, 2014; Kim, Natter, \& Spann, 2009). The limited B2B pricing strategies we identified include pay for performance (Hinterhuber \& Liozu, 2014), contingency pricing (Hinterhuber \& Liozu, 2014), profit sharing and coordinated pricing across multiple channels (Shankar, Inman, Mantrala, Kelley, \& Rizley, 2011; Yan, Pei, \& Myers, 2016), and to some extent advanced payment systems (Schulz, Schlereth, Mazar, \& Skiera, 2015).

Innovation around pricing strategies has the potential to disrupt entire industries (Schulz et al., 2015) and brings new approaches to solving tradition problems while improving customer satisfaction and organisation profits (Hinterhuber \& Liozu, 2014). Yet, as Hinterhuber \& Liozu (2014, p. 413) indicate "less than 5\% of companies have applied innovation to their pricing strategy, tactics or organization”, highlighting a large untapped potential for improvements in organisational performance.

Our review identified two main forces driving changes to pricing strategy, namely the development of information technology systems and changes to consumer behavior (Hinterhuber \& Liozu, 2014). Information technology allows organisations to process large amounts of real-time data to have a better understanding of market segments (Hinterhuber \& Liozu, 2014). While changes to consumer behavior encourages value offerings to be individualised using pay for performance strategies (Hinterhuber \& Liozu, 2014), and enables consumers to have some control over prices paid using participative pricing mechanisms (Kim et al., 2009).

\section{Distribution}

Decisions around channel choices, distribution structure and types of channel actors are "becoming as important and complex as the decisions about product features and prices" 
(Krafft, Goetz, Mantrala, Sotgiu \& Tillmanns 2015, p. 570). In recent years, innovations driven by forces around information technology, technical advancement, globalisation, customer behavior, and regulations have fundamentally reshaped trade and distribution sytems (Hulthén \& Gadde 2007; Reinartz, Dellaert, Drafft, Kumar \& Varadarajan, 2011; Sandgren, 2015; Elliot, Ngugi \& Malgwi, 2018; Shankar et al., 2011). Our review highlights two broad categories of innovation in distribution: new channel structure and new distribution activities. It should be noted that these categories are not independent but rather influence each other.

First, in terms of channel structure, traditional distribution channels focused on mass production and channel efficiency, where manufacturing organisations 'pushed' products through the supply chain such that consumers selected what they offered. Information technology developments, such as the rise of electronic buying behavior, drove channel restructuring from tradition channels to multi-channel retailing through to omni-channel retailing (Verhoef, Kannan \& Inman, 2015; Shankar et al., 2011). A major challenge with these changes is channel conflict for which innovative strategies were developed for channel coordination and improvements to channel performance (Yan, Pei \& Myers, 2016). These changes have further reinforced new power relationships between manufacturers and retailers (Hulthén \& Gadde, 2007; Krafft et al., 2015), and channel conflicts from the incompatible goals of actors participating in multi-channel arrangements (Yan et al., 2016; Krafft et al., 2015). These changes elicit the adoption of cooperative strategies such as the implementation of efficient customer response and category management innovations (Reinartz et al., 2011) or profit sharing and coordinative pricing across different channels (Yan et al., 2016).

The restructuring of distribution channels requires new skills which led to the emergence of new roles such as third party logistics suppliers and electronic intermediaries (Hulthén \& Gadde, 2007). Electronic intermediaries aim to make channels interchangeable and seamless such that the customer experience is so similar that differences between online and physical 
outlets don't exist (Verhoef et al., 2015). This is particularly important given that consumers use multiple retailer channels and "expect consistent information and seamless experience" across the different processes from pre-purchase through to returns (Shankar et al., 2011, p. 33).

Other examples of new intermediaries include the rise of mobile devices for money transfer services rather than physical money exchange within retail outlets (Reinartz et al, 2011; Elliot et al., 2018). Elliot et al., (2018) highlights how the rise of mobile phone providers as finance intermediaries within various developing countries has led to improvements in efficiency within the financial distribution channel; improved security; reductions in channel conflict and greater control over finances for all parties involved in the transactions.

The increase in pop-up stores is another example of changes to channel structure (Surchi, 2011). This is a significant marketing innovation as it changes how products are offered, relies on word-of-mouth promotion and has low start-up, fixed costs giving greater flexibility to brand managers on how their products are offered. Surchi (2011) highlights that these store formats change the shopping experience by offering entertainment and surprise, thus generating a greater emotional response from the shopper than traditional permanent store offerings.

Second, in terms of distribution activities, channels have had to improve their flexibility and product offerings to respond to consumer expectations and capitalise on technological developments. Requirements of greater customisation and individualisation with product offerings have led to distribution activities changing from speculative supply chain strategies to postponement strategies (Hulthén \& Gadde, 2007).

Progress in manufacturing technology, logistics and distribution reconfiguration has allowed manufacturers to provide their customers (in B2B settings) and/or end users (in B2C settings) 
with customised products and solutions (Hulthén \& Gadde, 2007; Reinartz et al., 2011). Mass customisation examples can be found in the automotive sector (cars with a choice of colours, seats, accessories and so), consumer electronics (laptop with choice of processor, memory, storage, and other equipment), and apparel (shoes and gear with the option to create unique colorways and add personalised text). Other distribution activities that emerged due to improvements in information technology include virtual shop testing (online store design mimic offline), virtual reality shopping experiences, and the use of RFID technology to follow products through the supply chain to highlight a few (Shankar et al., 2011). Each of these marketing innovations highlights how activities within the distribution channel are increasingly focusing on consumer interaction (Reinartz et al., 2011; Hulthén \& Gadde, 2007).

\section{Promotion}

The overwhelming majority of the articles tackling promotion innovation focus on the opportunities and impact of the digital revolution to communicate with customers. Technological developments such as online social networks, blogs, product rating websites, discussion forums, video sharing sites, and mobile devices to name a few have opened up opportunities to influence customers' attitude, both in the B2C and B2B context (Mangold \& Faulds, 2009; Shankar et al., 2011). Altogether, the rapid penetration of information technologies has enabled marketers to reach customers through new touchpoints for a variety of marketing objectives including market research, customer relationship management, service, and, most importantly, sales promotions (Ashley \& Tuten, 2015; Rapp, Beitelspacher, Grewal, \& Hughes, 2013).

A wide range of promotion innovations are discussed in the literature. For example, scholars have examined coupon offering on the Web, through email and via SMS on mobile phones (Persaud \& Azhar, 2012). In addition, location-sharing application providers such Shopkick, 
Loopt, and FourSquare are offering mobile coupons and loyalty programs to shoppers with mobile phones that might allow businesses to know where customers go once they enter the store, how much time they spend there, and what they ultimately buy (Shankar et al., 2011). This information might be used to create a very powerful database of customer behaviour to optimise promotion campaigns. As Hariharan et al. (2015, p. 270) remark: “Armed with improved targeting technology, firms are increasingly interested in optimizing their advertising dollars through segment-specific targeting, especially while introducing new products”.

Another common theme relates to the promotion of branding initiatives (Gupta et al., 2016; Chimhundu, Hamlin, \& McNeill, 2010). Innovative promotion strategies for branding include "paid display advertising, participating in social networks as a brand persona, branded engagement opportunities for customer participation within social networks, and content marketing (or social publishing)” (Ashley \& Tuten, 2015, p. 15). Social media campaigns encourage ongoing relationships between customers and the brand, provide insight into customers' needs and behaviours, and improve sales performance (Wang, Hsiao, Yang, \& Hajli, 2016; Nguyen et al., 2015)

Overall, the current revolution in information technology and digital communication marketing promotion has a profound impact on integrated marketing communications (IMC), which "attempts to coordinate and control the various elements of the promotional mix — advertising, personal selling, public relations, publicity, direct marketing, and sales promotion - to produce a unified customer-focused message” (Mangold \& Faulds, 2009, p. 357). While media have long been construed as a set of communication channels and intermediaries that provide access to desired audiences, digital connectivity dramatically expand the firm’s opportunities to interact with consumers (Mulhern, 2009). Firms can now communicate with their customers without the need for media organisations in order to provide a range of digital services and experience. 
Marketing Innovation as a single vs. multiple construct

Marketing innovation as a single construct draws on multiple marketing items being loaded onto one construct. The number of items we identified in the literature varied from three (e.g. Sánchez-Gutiérrez, Cabanelas, Lampón \& Gonzálex-Alvarado, 2019) to seven items (e.g. Lamey, Deleersnyder, Steenkamp and Dekimpe, 2012). All of these articles undertook a quantitative methodology and focused on either firm or inter-organisation level. This stream of articles investigated the influence of marketing innovations on firm performance (e.g. Merrilees, Rundle-Thiele \& Lye, 2016), value creation (Sánchez-Gutiérrez et al., 2019), new product performance (Naidoo, 2010), competition (e.g. Weerawardena \& O’Cass, 2004; Gupta et al., 2016), and markets (e.g. Srinivasan, Pauwels, Silva-Risso, \& Hanssens, 2009; Schubert, 2010),

A large proportion of the articles using a single construct (44\%) draw on the 'Community Innovation Survey' (CIS), administered by the European Union and various national governments. The CIS survey introduced the concept of marketing innovation in the 2002 questionnaire for Europe, with items drawn from the various versions of the Oslo Manual. All articles concentrated on a single country (e.g. Spain (Medrano \& Olarte-Pascual, 2016), Sweden (Tavassoli \& Karlsson, 2015), Germany (Grimpe et al., 2017), Chile (Geldes e al., 2017), Turkey (Hinteregger, Durst, Temel \& Yesilay, 2019).

However, several scholars also developed their own (single construct) measurement of marketing innovation. While some conceptualisations closely followed the instrument of the Community Innovation Survey (e.g. Naidoo, 2010), others focused on particular contexts (retail settings: Fuentes-Blasco, Moliner-Velázqez, Servera-Francés \& Gil-Saural, 2017) or compared innovative marketing capabilities to competitors (O’Cass \& Ngo, 2012). A small number of articles measured marketing innovation with items that don’t cover a broad range 
of marketing functions (e.g. Bortoluzzi, Kadic-Maglajlic, Arslanagic-Kalajdzic \& Balboni, 2018) leaving open the question as to whether they measured "marketing innovation" or another related construct.

In addition, a series of articles draw on multiple aspects of marketing innovation strategies and tactics within their research design. For example Allaway, Berkowitz and O’Souza (2003) examined the diffusion of a new loyalty program based on various aspects of the marketing effort and Park, Yu and Zhou (2010) showed how different customer segments reacted to different innovative marketing strategies. This group of articles relies on both quantitative and qualitative methodologies. Qualitative methodologies are typically aimed at focusing on the different aspects of marketing innovations, providing a rich, holistic perspective on a wide range of innovative marketing programs, capabilities, and tactics. For example Mariadoss, Tansuhaj and Houri (2011) investigated how innovative marketing capabilities are required to implement sustainability strategies. For their part, Nickell, Rollins and Hellman (2013) examined at how different innovative marketing strategies (customer relationship management; key account management, communication) contributed to the firms success during recessions. e

\section{DISCUSSION}

A number of patterns and trends at the core of marketing innovation emerge from the results detailed in the previous section and are illustrated in Figure 2. First, our review suggests the technological perspective around product and service innovation is still dominant in the marketing literature, and is shown as the central construct within Figure 2. The product's distance from (or proximity to) the current industry technological trajectory is a key indicator of innovation (Bartoloni \& Baussola, 2015; Rindova \& Petkova, 2007). Marketing innovation is often merged with product innovation, especially when examining the commercialisation of 
new products (Chiesa \& Frattini, 2011; Hsieh \& Tsai, 2007). For example, Garcia and Calantone (2002) consider innovativeness around two pillars: marketing discontinuities and technological discontinuities and they suggest that marketing skills are necessary when going from invention to marketplace. Therefore, marketing innovation can be complementary to technological innovations, rather than substitutes (Schubert, 2010; Veryzer, 2005). This focus on technology is not surprising considering that most of the early literature in innovation mostly deals with R\&D or technology factors such as access to information, acquirement of machinery and equipment (Medrano \& Olarte-Pascual, 2016).

Recently, a large number of studies have investigated how different aspects of marketing innovation interact with product innovation beyond the phase of product launch. Various combinations of marketing and product innovation, and even combinations of different aspects of marketing innovation have been highlighted, such as the role of "lead products" when firms communicate their brand values through product design (Karjalainen \& Snelders, 2010), the use of social media in branding results in fundamental changes to existing practices (Nguyen et al., 2015), the impact of e-retail websites on overall e-service quality (O’Cass \& Carlson, 2012), and the impact of marketing communications digitisation on the different sets of practices for connecting consumers and brands (Mulhern, 2009) to name a few.

Second, our review highlights that branding is a core aspect of the literature on marketing innovation and is included in Figure 2 circling the new product construct. In this context, branding enables "how meaning is formed and mediated by signs that are embodied in products and recognized by others” (Karjanlainen \& Snelders, 2009, p. 9). Brands increasingly utilise social media to develop novel brand building practices which help them connect with users in order to create meaning and to foster a sense of belonging through the engagement itself. Accordingly, we suggest that branding should also be included in the definition of marketing innovation. An amended definition could be: "new marketing methods involving significant 
changes in the design or packaging, brand, distribution, promotion and pricing of product and/or service offerings". Also this definition includes services given recent trends of investigating marketing innovation from a service-dominant logic approach where products and services are becoming bundled into a single core offering. Another trend is the recent inclusion of marketing innovation (as a single construct) within the research design. As outlined in Table 1 the conceptualisation of marketing innovation as a combination of marketing components has increased in the literature post 2010.

Third, technology (e.g., bar codes, QR codes, mobile phones, augmented reality, RFD chips, 3-D digital modelling, geolocation, machine learning and so on) becomes ubiquitous in all aspects of marketing innovation as shown through the results section. Digitisation, including the integration of internet-connected digital technologies, has profoundly affected marketing activities, processes and actors. Digital and mobile marketing offer new ways to reach, inform, engage, sell to, learn about, and provide service to customers (Lamberton \& Stephen, 2016). For example, a company can sell their services through different online channels (company website, metasearch engine, price comparison websites, or product marketplaces such as eBay and Amazon) by managing on-demand capacity to enable dynamic pricing and with a live chat which provides a human touch. In other words, digitisation provides multiple avenues for marketing innovation along exchanges (including communications and distribution); the nature of offerings (what constitutes the actual offering and how it is priced); transaction settings (i.e. where and when the sale takes place); and the actors who participate in the transaction (i.e. retailers, consumers, among other intermediaries) (Hagberg, Sundstrom, \& Egels-Zandén, 2016).

The ubiquity of technology also has implications for the definition of marketing innovation and how we define this in the future. It could be argued that marketing innovation and technological innovation surrounding new products and services should be further integrated into a common 
approach. For example, Pay What You Want incorporates the customers as creating value through creating their own price, thus involved in the product/service offering rather than as an organisational business process. Yet, the OECD (2018) has recently categorised aspects of marketing innovation within business process innovations and product design (for which the marketing function plays an important role) as part of technological innovation. Thus, if marketing innovation processes are core for the product offering, questions can be raised about whether marketing and technological innovation should be separately defined.

Fourth, the results of this review indicate that investigating marketing innovation from the theoretical perspectives of co-creation, service-dominant logic and industrial network/relationship marketing approaches is a recent trend with the earliest articles beginning around 2008 and 56\% of publication output being from 2015 onwards. The rising trend in using these perspectives highlights recognition in taking a more external focus and involving actors outside of the firm within the marketing innovation process. In particular, this trend stresses the importance of customer engagement to bring ideas and knowledge from user communities that facilitates product introduction and brand awareness, thereby facilitating co-creation practices (Wang et al., 2016). As shown in our review, a growing number of articles suggested various ways to better engage with customers (Cui \& Wu, 2016; Fernandes \& Remelhe, 2016; Santos-Vijande et al., 2016). Yet, Griffin, et al. (2013) indicated that customer engagement is a difficult topic for firms, especially in B2B context, and this provides significant potential for future research.

\section{SUGGESTIONS FOR FUTURE RESEARCH}

Our review reveals several opportunities for further insight into marketing innovation and to expand the research techniques used to date. In relation to research techniques, the review highlighted a number of areas where the strengths of interpretative methods may benefit a 
research focus on marketing innovations. Our results highlighted themes which would benefit from interpretative methods. For example, Hauser, Tellis and Griffin (2016) indicated that temporality is an important issue in commercialising marketing innovations, where interpretative methods often are better suited to temporal studies. Other examples of themes include the inclusion of external actors within marketing innovation processes or supporting marketing innovation processes influence outcomes; the development of co-ordinated cooperative strategies required for omni-channel distribution; teasing out the interactions between the different marketing innovation aspects. Our argument is not that quantitative approaches should be ignored but rather that qualitative and alternative approaches may be considered advantageous.

Suggestions for future research around marketing innovation topics would include the area of pricing strategies. This review has highlighted that there is limited research conducted on marketing innovation focusing on pricing, and particularly B2B pricing strategies. Academic literature is sporadic, making it difficult to draw from multiple studies to build theoretical developments on new pricing techniques. For example, Schulz et al., (2015) highlight that in relation to advanced payment systems more research is required around how changing payment structures can offer different value experiences across multiple customer segments.

The drive to put more distribution activities closer to the end consumer requires more focus on the possible impacts to efficiency and effectiveness within distribution channels. Cost structures and channel controls are changing with consumers 'undertaking more of these tasks themselves' thus, requiring research to consider changes to channel governance controls and information flows and their impact on end consumer value experiences.

Lastly, the velocity of new promotional innovations reaching customers has highlighted that research into how information obtained from different promotional channels, such as social 
media, social networks, peer-to-peer communications, needs to be integrated to improve the targeting of communications (Hariharan et al., 2015). Using this information to improve predictability around customer behaviour including search, decision and spending processes, can improve optimisation of promotional campaigns. Therefore, focusing on how to bring together multiple touch points that are quickly changing to analyse, develop and implement promotional campaigns is a critical problem.

\section{CONCLUSION}

In this review, we consider innovation and marketing as the two sides of the same coin, in line with Wiersema (2013) who contends that innovation and marketing should not be separate islands. Today, the concepts of marketing and innovation are increasingly brought closer to capture a specific type of innovation driving marketing practices underpinning the development and commercialisation of products and services along the design, branding, distribution, promotion and pricing dimensions.

Our review shows that a vast stream of literature in marketing journals primarily focuses on product and service innovation, examining change in product attributes based on a modification of underlying technologies. Marketing innovation is often seen as complementary to product innovation, a large number of artciles in this review consider aspects pertaining to both product and marketing innovation, thereby blurring concepts of product, design, and brand for example. Digitalisation further accentuates the blurring of boundaries as exchanges are being transformed through changes in transactions, communication, and distribution. A minority of articles in our review focus on marketing innovation as a single construct. A notable proportion of articles in this stream of literature draw on data from the Community Innovation Survey and follow the Oslo Manual (OECD, 2005; 2018) for the definition of marketing innovation 
Marketing innovation research is therefore fragmented and not fully tested in all areas. One possible explanation for this lack of research on marketing innovation may be linked to the fact that the concept is relatively new. Only in 2005 was marketing innovation included in the Oslo Manual's definition of innovation leading to increased data collection on marketing innovation in OECD countries. Another explanation is that the different aspects of marketing innovation are often lumped together with the product and service and that it is difficult to disentangle theses aspects both in the business world and in academic publications.

The implementation each " $\mathrm{P}$ "' of the marketing-mix might have to change to achieve the full potential of marketing innovation. Value pricing, cross-selling, fast introduction, agreements with partners on exclusivity, co-branding and co-marketing, consultative selling and customer co-creation have been indicated as the right tools here (Matthyssens et al., 2006). Increasingly, marketers need to combine various marketing innovations to reach out to their customers and create new value for them. This calls for marketing practices and strategies which align innovative product offering with a strong brand reinforcing perceived value, design to facilitate the accomplishment of the task and increase aesthetic experiences, optimal targeting of advertisement, and a pricing method that can capture the attention of customers and forge new relationships with them.

Drucker’s (1954) quote regarding marketing and innovation being the primary functions of a business remind us that marketing innovation can serve as a catalyst to create new marketspaces by looking at new approaches to value creation, reaching out to other disciplines, drawing on the advances and proliferation of new media and channels, empowering consumers and employees, and fostering collaboration with stakeholders via technology-enabled exchange. Threatened by disruption and relentless technological change, companies which adopt marketing innovation practices and engage in proactive strategies will be ideally placed to gain an enduring competitive advantage. 


\section{References}

Aaker, D. A. (2007). Innovation: brand it or lose it. California Management Review, 50(1), 824.

Agarwal, S., Krishna Erramilli, M., \& Dev, C. S. (2003). Market orientation and performance in service firms: role of innovation. Journal of services marketing, 17(1), 68-82.

Allaway, A. W., Berkowitz, D., \& D’Souza, G. (2003). Spatial diffusion of a new loyalty program through a retail market. Journal of Retailing, 79(3), 137-151.

Anselmsson, J., \& Johansson, U. (2009). Retailer brands and the impact on innovativeness in the grocery market. Journal of Marketing Management, 25(1-2), 75-95.

Ashley, C., \& Tuten, T. (2015). Creative strategies in social media marketing: An exploratory study of branded social content and consumer engagement. Psychology \& Marketing, 32(1), 15-27.

Atuahene-Gima, K. (2005). Resolving the Capability - Rigidity Paradox in New Product Innovation. Journal of Marketing, 69(4), 61-83.

Balan, C. (2014). Pay what you want: A participative price setting mechanism. International Journal of Economic Practices and Theories, 4, 952-963.

Bass, F. M. (1969). A new product growth for model consumer durables. Management Science, 15(5), 215-227.

Bartoloni, E., \& Baussola, M. (2015). Does technological innovation undertaken alone have a real pivotal role? Economics of Innovation and New Technology, 25(2), 91-113.

Becheikh, N., Landry, R., \& Amara, N. (2006). Lessons from innovation empirical studies in the manufacturing sector: A systematic review of the literature from 1993-2003. Technovation, 26(5), 644-664.

Bengtsson, M., Boter, H., \& Vanyushyn, V. (2007). Integrating the internet and marketing operations: a study of antecedents in firms of different size. International Small Business Journal, 25(1), 27-48.

Berghman, L., Matthyssens, P., \& Vandenbempt, K. (2012). Value innovation, deliberate learning mechanisms and information from supply chain partners. Industrial Marketing Management, 41(1), 27-39.

Bertini, M., Gourville, J., \& Ofek, E. (2011). The best way to name your product 2.0. 
Harvard Business Review, May, 89(5), 36

Beverland, M. (2005). Managing the Design Innovation-Brand Marketing Interface: Resolving the Tension between Artistic Creation and Commercial Imperatives. Journal of Product Innovation Management, 22, 193-207.

Beverland, M. B., Napoli, J., \& Farrelly, F. (2010). Can all brands innovate in the same way? A typology of brand position and innovation effort. Journal of Product Innovation Management, 27(1), 33-48.

Bloch, P. (1995). Seeking the Ideal Form: Product Design and Consumer Response. Journal of Marketing, 59(3), 16-29.

Boisvert, J., \& Ashill, N. J. (2011). How brand innovativeness and quality impact attitude toward new service line extensions: The moderating role of consumer involvement. Journal of Services Marketing, 25(7), 517-527.

Bonney, F., \& Williams, B. (2009). From products to solutions: the role of salesperson opportunity recognition. European Journal of Marketing, 43(7/8), 1032-1052.

Bortoluzzi, G., Kadic-Maglajlic, S., Arslanagic-Kalajdzic, M., \& Balboni, B. (2018). Innovativeness as a driver of the international expansion of developing markets' firms: evidence of curvilinear effects. International Marketing Review, 35(2), 215-235.

Boyd, T. C., \& Mason, C. H. (1999). The link between attractiveness of "extrabrand" attributes and the adoption of innovations. Journal of the Academy of Marketing Science, 27(3), 306-319.

Brettel, M., Heinemann, F., Engelen, A., \& Neubauer, S. (2011). Cross-Functional Integration of R\&D, Marketing, and Manufacturing in Radical and Incremental Product Innovations and Its Effects on Project Effectiveness and Efficiency. Journal of Product Innovation Management, 28(2), 251-269. doi:10.1111/j.1540-5885.2011.00795.x

Brexendorf, T. O., Bayus, B., \& Keller, K. L. (2015). Understanding the interplay between brand and innovation management: findings and future research directions. Journal of the Academy of Marketing Science, 43(5), 548-557.

Burki, U., \& Dahlstrom, R. (2017). Mediating effects of green innovations on interfirm cooperation. Australasian Marketing Journal, 25(2), 149-156.

Cadwallader, S., Jarvis, C. B., Bitner, M. J., \& Ostrom, A. L. (2010). Frontline employee 
motivation to participate in service innovation implementation. Journal of the Academy of Marketing Science, 38(2), 219-239.

Camisón, C., \& Villar-López, A. (2011). Organizational innovation as an enabler of technological innovation capabilities and firm performance. Journal of Business Research, 67, 2891-2902.

Chandy, R., \& Tellis, G. (2000). The incumbent's curse? Incumbency, size, and radical product innovation. Journal of marketing, 64(3), 1-17

Chen, Y., \& Zhang, T. (2015). Interpersonal bundling. Management Science, 61(6), 14561471.

Chiesa, V., \& Frattini, F. (2011). Commercializing technological innovation: Learning from failures in high-tech markets. Journal of Product Innovation Management, 28(4), 437454.

Chimhundu, R., Hamlin, R., \& McNeill, L. (2010). Impact of manufacturer brand innovation on retailer brands. International Journal of Business and Management, 5(9), 10.

Cruz-Ros, S., Garzon, D., \& Mas-Tur, A. (2017). Entrepreneurial competencies and motivations to enhance marketing innovation in Europe. Psychology \& Marketing, 34(11), 1031-1038.

Cui, A. S., \& Wu, F. (2016). Utilizing customer knowledge in innovation: antecedents and impact of customer involvement on new product performance. Journal of the Academy of Marketing Science, 44(4), 516-538.

Choi, H., Kim, S. H., \& Lee, J. (2010). Role of network structure and network effects in diffusion of innovations. Industrial Marketing Management, 39(1), 170-177.

Claudy, M. C., Garcia, R., \& O’Driscoll, A. (2015). Consumer resistance to innovation-a behavioral reasoning perspective. Journal of the Academy of Marketing Science, 43(4), 528-544.

Cornell University, INSEAD, and WIPO (2018): The Global Innovation Index 2018: Energizing the Worldwith Innovation. Ithaca, Fontainebleau, and Geneva.

D'Antone, S., Canning, L., Franklin-Johnson, E., \& Spencer, R. (2017). Concerned innovation: The ebb and flow between market and society. Industrial Marketing Management, 64, 66-78. 
De Luca, L.M., \& Atuahene-Gima, K. (2007). Market knowledge dimensions and crossfunctional collaboration: Examining the different routes to product innovation performance. Journal of Marketing, 71(1), 95-112.

Drucker, P. (1954), The Practice of Management, Harper, New York; revised edition, Butterworth-Heinemann, 2007.

Dutta, S., Narasimhan, O., \& Rajiv, S. (1999). Success in high technology markets: Is marketing capability critical?. Marketing Science, 18(4), 547-568.

Dotzel, T., Shankar, V., \& Berry, L. (2013). Service innovativeness and firm value. Journal of Marketing Research, 50(2), 259-276.

Elliot, E. A., Ngugi, B., \& Malgwi, C. A. (2018). Mitigating microfinance marketing channels inefficiencies with customerization of mobile technology. International Marketing Review, 35(4), 619-636.

Eggert, A., Thiesbrummel, C., \& Deutscher, C. (2015). Heading for new shores: Do service and hybrid innovations outperform product innovations in industrial companies? Industrial Marketing Management, 45(1), 173-183.

Eriksson, K., Kerem, K., \& Nilsson, D. (2008). The adoption of commercial innovations in the former Central and Eastern European markets: The case of internet banking in Estonia. International Journal of Bank Marketing, 26(3), 154-169.

Ernst, H., Kahle, H.N., Dubiel, A., Prabhu, J. \& Subramaniam, M. (2015). The Antecedents and Consequences of Affordable Value Innovations for Emerging Markets. Journal of Product Innovation Management, 32(1), 65-79.

European Union (2017), European Innovation Scoreboard 2017, doi:10.2873/076586, http://ec.europa.eu/growth/industry/innovation/facts-figures/scoreboards accessed at 7 November, 2019.

Fang, E., Palmatier, R. W., \& Evans, K. R. (2008). Influence of customer participation on creating and sharing of new product value. Journal of the Academy of Marketing Science, 36(3), 322-336.

Fell, D. R., Hansen, E. N., \& Becker, B. W. (2003). Measuring innovativeness for the adoption of industrial products. Industrial Marketing Management, 32(4), 347-353.

Fell, D. R., Hansen, E. N., \& Becker, B. W. (2003). Measuring innovativeness for the 
adoption of industrial products. Industrial Marketing Management, 32(4), 347-353.

Fernandes, T., \& Remelhe, P. (2016). How to engage customers in co-creation: customers’ motivations for collaborative innovation. Journal of Strategic Marketing, 24(3-4), 311-326.

Foxall, G. R. (1988). Marketing new technology: Markets, hierarchies, and user-initiated innovation. Managerial and Decision Economics, 9(3), 237-250.

Fuentes-Blasco, M., Moliner-Velázquez, B., Servera-Francés, D., \& Gil-Saura, I. (2017). Role of marketing and technological innovation on store equity, satisfaction and wordof-mouth in retailing. Journal of Product \& Brand Management, 26(6), 650-666.

Garcia, R. \& Calantone, R. (2002). A critical look at technological innovation typology and innovativeness terminology: A literature review. Journal of Product Innovation Management, 19, 110-132.

Geldes, C., Felzensztein, C., \& Palacios-Fenech, J. (2017). Technological and nontechnological innovations, performance and propensity to innovate across industries: The case of an emerging economy. Industrial Marketing Management, 61, 55-66.

Griffin, A., Josephson, B.W., Lilien, G., Wiersema, F., Bayus, B., Chandy, R., Spanjol, J. (2013). Marketing's roles in innovation in business-to-business firms: Status, issues, and research agenda. Marketing Letters, 24(4), 323-337.

Grimpe, C., Sofka, W., Bhargava, M., \& Chatterjee, R. (2017). R\&D, marketing innovation, and new product performance: a mixed methods study. Journal of Product Innovation Management, 34(3), 360-383.

Günther, M., Stummer, C., Wakolbinger, L. M., \& Wildpaner, M. (2011). An agent-based simulation approach for the new product diffusion of a novel biomass fuel. Journal of the Operational Research Society, 62(1), 12-20.

Gupta, S., Malhotra, N.K., Czinkota, H. \& Foroudi, P. (2016). Marketing innovation: A consequence of competitiveness. Journal of Business Research, 69, 5671-5681.

Hagberg, J., Sundstrom, M., \& Egels-Zandén, N. (2016). The digitalization of retailing: an exploratory framework. International Journal of Retail \& Distribution Management, 44(7), 694-712. 
Han, J., Kim, N., \& Srivastava, R. (1998). Market orientation and organizational performance: is innovation a missing link? Journal of Marketing, 62(4), 30-45.

Hariharan, V. G., Talukdar, D., \& Kwon, C. (2015). Optimal targeting of advertisement for new products with multiple consumer segments. International Journal of Research in Marketing, 32(3), 263-271.

Hauser, J., Tellis, G. J., \& Griffin, A. (2006). Research on innovation: A review and agenda for marketing science. Marketing science, 25(6), 687-717.

Heiskanen, E., \& Matschoss, K. (2016). Consumers as innovators in the electricity sector? Consumer perceptions on smart grid services. International Journal of Consumer Studies, 40(6), 665-674.

Homburg, C., Schwemmle, M., \& Kuehnl, C. (2015). New product design: Concept, measurement, and consequences. Journal of Marketing, 79(3), 41-56.

Harmancioglu, N., Droge, C., \& Calantone, R. J. (2009). Theoretical lenses and domain definitions in innovation research. European Journal of Marketing, 43(1/2), 229-263.

Hinteregger, C., Durst, S., Temel, S., \& Yesilay, R. B. (2019). The impact of openness on innovation in SMEs. International Journal of Innovation Management, 23(01), 1950003.

Hinterhuber, A., \& Liozu, S. M. (2014). Is innovation in pricing your next source of competitive advantage?. Business Horizons, 57(3), 413-423.

Hsieh, M. H., \& Tsai, K. H. (2007). Technological capability, social capital and the launch strategy for innovative products. Industrial Marketing Management, 36(4), 493-502.

Hulthén, K., \& Gadde, L. (2007). Understanding the new distribution reality through old concepts: a renaissance for transvection and sorting. Marketing Theory, 7(2), 184-207.

Hyysalo, S., Repo, P., Timonen, P., Hakkarainen, L., \& Heiskanen, E. (2016). Diversity and change of user driven innovation modes in companies. International Journal of Innovation Management, 20(02), 1650023.

Jaw, C., Lo, J.Y., \& Lin, Y.H. (2010). The determinants of new service development: Service characteristics, market orientation, and actualizing innovation effort. Technovation, 30(4), 265-277. 
Jürgensen, K., \& Guesalaga, R. (2018). Young consumers’ innovativeness in apparel choices: A model including consumer self-confidence. International Journal of Consumer Studies, 42(2), 255-263.

Kafetzopoulos, D., \& Psomas, E. (2016). Organisational learning, non-technical innovation and customer satisfaction of SMEs. International Journal of Innovation Management, 20(03), 1650041.

Karjalainen, T. M., \& Snelders, D. (2010). Designing visual recognition for the brand. Journal of Product Innovation Management, 27(1), 6-22.

Keller, K. L. (2012). Understanding the richness of brand relationships: Research dialogue on brands as intentional agents. Journal of Consumer Psychology, 22(2), 186-190.

Kim, J.Y., Natter, M. \& Spann, M. (2009). Pay what you want: A new participative pricing mechanism. Journal of Marketing, 73, 44-58.

Kim, S. J., Kim, K. H., \& Choi, J. (2017). The Role of Design Innovation in Understanding Purchase Behavior of Augmented Products. Journal of Business Research. https://doi.org/10.1016/j.jbusres.2017.09.047

Kjellberg, H., Azimont, F., \& Reid, E. (2015). Market innovation processes: Balancing stability and change. Industrial Marketing Management, 44, 4-12.

Krafft, M., Goetz, O., Mantrala, M., Sotgiu, F., \& Tillmanns, S. (2015). The evolution of marketing channel research domains and methodologies: an integrative review and future directions. Journal of Retailing, 91(4), 569-585.

Lamberton, C., \& Stephen, A. T. (2016). A thematic exploration of digital, social media, and mobile marketing: Research evolution from 2000 to 2015 and an agenda for future inquiry. Journal of Marketing, 80(6), 146-172.

Lamey, L., Deleersnyder, B., Steenkamp, J.-B. E., \& Dekimpe, M. G. (2012). The effect of business-cycle fluctuations on private-label share: what has marketing conduct got to do with it? Journal of Marketing, 76(1), 1-19.

Laukkanen, T., Sinkkonen, S., Kivijärvi, M., \& Laukkanen, P. (2007). Innovation resistance among mature consumers. Journal of Consumer Marketing, 24(7), 419-427.

Laursen, L. N., \& Andersen, P. H. (2016). Innovation summits: comparison and conceptualisation. European Journal of Marketing, 50(12), 2249-2268. 
Lee, R., Lee, J.-H., \& Garrett, T. C. (2019). Synergy effects of innovation on firm performance. Journal of Business Research, 99, 507-515.

Lee, S., \& Johnson, Z. S. (2017). The effect of new product design and innovation on South Korean consumer's willingness to buy. Asia Pacific Journal of Marketing and Logistics, 29(1), 98-113.

Li, T., \& Calantone, R. J. (1998). The impact of market knowledge competence on new product advantage: conceptualization and empirical examination. The Journal of Marketing, 1329.

Love, J. H., \& Roper, S. (2009). Organizing innovation: complementarities between crossfunctional teams. Technovation, 29(3), 192-203.

Mahr, D., Lievens, A., \& Blazevic, V. (2014). The Value of Customer Cocreated Knowledge during the Innovation Process. Journal of Product Innovation Management, 31(3), 599615. doi:10.1111/jpim.12116

Mangold, W. G., \& Faulds, D. J. (2009). Social media: The new hybrid element of the promotion mix. Business horizons, 52(4), 357-365.

Mariadoss, B. J., Tansuhaj, P. S., \& Mouri, N. (2011). Marketing capabilities and innovation-based strategies for environmental sustainability: An exploratory investigation of B2B firms. Industrial Marketing Management, 40(8), 1305-1318.

Matthyssens, P., Vandenbempt, K., \& Berghman, L. (2006). Value innovation in business markets: Breaking the industry recipe. Industrial Marketing Management, 35(6), 751761.

Medrano, N., \& Olarte-Pascual, C. (2016). The effects of the crisis on marketing innovation: an application for Spain. Journal of Business \& Industrial Marketing, 31(3), 404-417.

Mena, J. A., \& Chabowski, B. R. (2015). The role of organizational learning in stakeholder marketing. Journal of the Academy of Marketing Science, 43(4), 429-452.

Merrilees, B., Rundle-Thiele, S., \& Lye, A. (2011). Marketing capabilities: Antecedents and implications for B2B SME performance. Industrial Marketing Management, 40(3), 368375.

Michel, S., Brown, S. W., \& Gallan, A. S. (2008). An expanded and strategic view of discontinuous innovations: deploying a service-dominant logic. Journal of the Academy 
of Marketing Science, 36(1), 54-66.

Mothe, C., \& Nguyen, T. (2012). Non technological and technological innovations: Do services differ from manufacturing? An empirical analysis of Luxembourg firms. International Journal of Technology Management, 57(4), 227-244.

Mugge, R., \& Schoormans, J. P. (2012). Product design and apparent usability. The influence of novelty in product appearance. Applied ergonomics, 43(6), 1081-1088.

Mugge, R., \& Dahl, D. W. (2013). Seeking the ideal level of design newness: Consumer response to radical and incremental product design. Journal of Product Innovation Management, 30(S1), 34-47.

Mulhern, F. (2009). Integrated marketing communications: From media channels to digital connectivity. Journal of marketing communications, 15(2-3), 85-101.

Naidoo, V. (2010). Firm survival through a crisis: The influence of market orientation, marketing innovation and business strategy. Industrial Marketing Management, 39(8), 1311-1320.

Nickell, D., Rollins, M., \& Hellman, K. (2013). How to not only survive but thrive during recession: a multi-wave, discovery-oriented study. Journal of Business \& Industrial Marketing, 28(5), 455-461.

Ngo, L. V., \& O'Cass, A. (2012). In search of innovation and customer-related performance superiority: The role of market orientation, marketing capability, and innovation capability interactions. Journal of Product Innovation Management, 29(5), 861-877.

Nguyen, B., Yu, X., Melewar, T. C., \& Chen, J. (2015). Brand innovation and social media: Knowledge acquisition from social media, market orientation, and the moderating role of social media strategic capability. Industrial Marketing Management, 51, 11-25.

O’Cass, A., \& Carlson, J. (2012). An e-retailing assessment of perceived website-service innovativeness: Implications for website quality evaluations, trust, loyalty and word of mouth. Australasian Marketing Journal, 20(1), 28-36.

O'Cass, A., \& Ngo, L. V. (2012). Creating superior customer value for B2B firms through supplier firm capabilities. Industrial Marketing Management, 41(1), 125-135.

O'Cass, A., \& Weerawardena, J. (2009). Examining the role of international entrepreneurship, innovation and international market performance in SME 
internationalisation. European Journal of Marketing, 43(11), 1325-1348.

O'Dwyer, M., Gilmore, A., \& Carson, D. (2009a). Innovative marketing in SMEs.

European Journal of Marketing, 43(1/2), 46-61.

O'Dwyer, M., Gilmore, A., \& Carson, D. (2009). Innovative marketing in SMEs: An empirical study. Journal of Strategic Marketing, 17, 383-396.

OECD/Eurostat. (2005). Oslo Manual: Guidelines for collecting and interpreting innovation data, $3^{\text {rd }}$ edition, OECD Publishing, Paris.

OECD/Eurostat (2018). Oslo Manual 2018: Guidelines for Collecting, Reporting and Using Data on Innovation, $4^{\text {th }}$ edition, The Measurement of Scientific, Technological and Innovation Activities, OECD Publishing, Paris/ Eurostat, Luxembourg. https://doi.org/10.1787/9789264304604-en.

Onyas, W. I., \& Ryan, A. (2015). Agencing markets: Actualizing ongoing market innovation. Industrial Marketing Management, 44, 13-21.

Page, C., \& Herr, P. (2002). An investigation of the processes by which product design and brand strength interact to determine initial affect and quality judgments. Journal of Consumer Psychology, 12(2), 133-147.

Park, J.E., Yu, J., \& Zhou, J.X. (2010). Consumer innovativeness and shopping styles. Journal of Consumer Marketing, 27(5), 437-446.

Perks, H., \& Moxey, S. (2011). Market-facing innovation networks: How lead firms partition tasks, share resources and develop capabilities. Industrial Marketing Management, 40(8), 1224-1237.

Persaud, A., \& Azhar, I. (2012). Innovative mobile marketing via smartphones: Are consumers ready?. Onyas, W. I., \& Ryan, A. (2015). Agencing markets: Actualizing ongoing market innovation. Industrial Marketing Management, 44, 13-21.

Pino, C., Felzensztein, C., Zwerg-Villegas, A. M., \& Arias-Bolzmann, L. (2016). Nontechnological innovations: Market performance of exporting firms in South America. Journal of Business Research, 69(10), 4385-4393.

Puhakka, R., Valve, R., \& Sinkkonen, A. (2018). Older consumers’ perceptions of functional foods and non-edible health-enhancing innovations. International Journal of Consumer Studies, 42(1), 111-119. 
Purchase, S., Kum, C., \& Olaru, D. (2106). Paths, events, and resource use: new developments in understanding innovation processes. Industrial Marketing Management, 58, 123-136.

Ramirez, F. J., Parra-Requena, G., Ruiz-Ortega, M. J., \& Garcia-Villaverde, P. M. (2018). From external information to marketing innovation: the mediating role of product and organizational innovation. Journal of Business \& Industrial Marketing, 33(5), 693-705.

Rampersad, G., Quester, P., \& Troshani, I. (2010). Managing innovation networks:

Exploratory evidence from ICT, biotechnology and nanotechnology networks. Industrial Marketing Management, 39(5), 793-805.

Rapp, A., Beitelspacher, L. S., Grewal, D., \& Hughes, D. E. (2013). Understanding social media effects across seller, retailer, and consumer interactions. Journal of the Academy of Marketing Science, 41(5), 547-566.

Reinartz, W., Dellaert, B., Krafft, M., Kumar, V., \& Varadarajan, R. (2011). Retailing innovations in a globalizing retail market environment. Journal of Retailing, 87, 53-66.

Reydet, S., \& Carsana, L. (2017). The effect of digital design in retail banking on customers' commitment and loyalty: The mediating role of positive affect. Journal of Retailing and Consumer Services, 37, 132-138.

Rindova, V. P., \& Petkova, A. P. (2007). When is a new thing a good thing? Technological change, product form design, and perceptions of value for product innovations. Organization Science, 18(2), 217-232.

Rogers, E. M. (1962). Diffusion of innovations. Simon and Schuster.

Rosenzweig, S. (2017). Non-customers as initiators of radical innovation. Industrial Marketing Management, 66, 1-12.

Rubera, G., \& Kirca, A. H. (2017). You gotta serve somebody: the effects of firm innovation on customer satisfaction and firm value. Journal of the Academy of Marketing Science, 45(5), 741-761.

Sandgren, F. (2016). Toward a Simple Framework for Writing Histories of the Distributive Trades. Journal of Macromarketing, 36(3), 287-303.

Sánchez-Gutiérrez, J., Cabanelas, P., Lampón, J. F., \& González-Alvarado, T. E. (2019). The impact on competitiveness of customer value creation through relationship capabilities and marketing innovation. Journal of Business \& Industrial Marketing, 
34(3), 618-627.

Santos-Vijande, M. L., López-Sánchez, J. Á., \& Rudd, J. (2016). Frontline employees’ collaboration in industrial service innovation: routes of co-creation's effects on new service performance. Journal of the Academy of Marketing Science, 44(3), 350-375.

Schubert, T. (2010). Marketing and organisational innovations in entrepreneurial innovation processes and their relation to market structure and firm characteristics. Review of Industrial Organization, 36(2), 189-212.

Schulz, F., Schlereth, C., Mazar, N. \& Skiera, B. (2015). Advance Payment Systems: Paying Too Much Today and Being Satisfied Tomorrow. International Journal of Research in Marketing, 32 (3), 238-250.

Sharma, S., Conduit, J., \& Rao Hill, S. (2014). Organisational capabilities for customer participation in health care service innovation. Australasian Marketing Journal, 22(3), 179-188.

Shankar, V., Inman, J. J., Mantrala, M., Kelley, E., \& Rizley, R. (2011). Innovations in shopper marketing: current insights and future research issues. Journal of Retailing, 87, S29-S42.

Sheng, M. L. (2017). A dynamic capabilities-based framework of organizational sensemaking through combinative capabilities towards exploratory and exploitative product innovation in turbulent environments. Industrial Marketing Management, 65, 28-38.

Shergill, G. S., \& Nargundkar, R. (2005). Market orientation, marketing innovation as performance drivers: extending the paradigm. Journal of Global Marketing, 19(1), 2747.

Skålén, P., Gummerus, J., von Koskull, C., \& Magnusson, P. R. (2014). Exploring value propositions and service innovation: a service-dominant logic study. Journal of the Academy of Marketing Science, 43(2), 137-158.

Slater, S. \& Narver, J. (1994). Market orientation, customer value, and superior performance. Business Horizons, 37(2), 22-28.

Slater S. \& Narver J. (1999). Market-oriented is more than being customer-led, Strategic Management Journal, 20(12), 1165-1168.

Sok, P., O'Cass, A., \& Sok, K. M. (2013). Achieving superior SME performance: 
Overarching role of marketing, innovation, and learning capabilities. Australasian Marketing Journal, 21(3), 161-167.

Sok, P., \& O'Cass, A. (2015). Examining the new product innovation-performance relationship: Optimizing the role of individual-level creativity and attention-todetail. Industrial Marketing Management, 47, 156-165.

Song, M., \& Thieme, J. (2009). The role of suppliers in market intelligence gathering for radical and incremental innovation. Journal of Product Innovation Management, 26(1), 43-57.

Spring, M., \& Araujo, L. (2013). Beyond the service factory: Service innovation in manufacturing supply networks. Industrial Marketing Management, 42(1), 59-70.

Srinivasan, R., Lilien, G. L., Rangaswamy, A., Pingitore, G. M., \& Seldin, D. (2012). The total product design concept and an application to the auto market. Journal of Product Innovation Management, 29(S1), 3-20.

Srinivasan, S., Pauwels, K., Silva-Risso, J., \& Hanssens, D. M. (2009). Product innovations, advertising, and stock returns. Journal of Marketing, 73(1), 24-43.

Stock, R. M., Six, B., \& Zacharias, N. A. (2013). Linking multiple layers of innovationoriented corporate culture, product program innovativeness, and business performance: A contingency approach. Journal of the Academy of Marketing Science, 41(3), 283-299.

Storbacka, K., \& Nenonen, S. (2015). Learning with the market: Facilitating market innovation. Industrial Marketing Management, 44, 73-82.

Story, V., Hart, S., \& O'Malley, L. (2009). Relational resources and competences for radical product innovation. Journal of Marketing Management. 25(5-6), 461-481.

Surchi, M. (2011). The temporary store: a new marketing tool for fashion brands. Journal of Fashion Marketing and Management: An International Journal, 15(2), 257-270.

Tabeau, K., Gemser, G., Hultink, E. J., \& Wijnberg, N. M. (2017). Exploration and exploitation activities for design innovation. Journal of Marketing Management, 33(3-4), 203-225.

Tavassoli, S., \& Karlsson, C. (2015). Persistence of various types of innovation analyzed and explained. Research policy, 44(10), 1887-1901.

Thornhill, S. (2006). Knowledge, innovation and firm performance in high- and lowtechnology regimes. Journal of Business Venturing, 21(5), 687-703. 
Tranfield, D., Denyer, D., \& Smart, P. (2003). Towards a methodology for developing evidence-informed management knowledge by means of systematic review. British Journal of Management, 14(3), 207-222.

Tsou, H.T., Chen, J.S., \& Liao, W.H. (2014). Market and technology orientations for service delivery innovation: the link of innovative competence. Journal of Business \& Industrial Marketing, 29(6), 499-513.

Tsourvakas, G., Monastiridis, P., Goulaptsi, I., \& Dekoulou, P. (2016). The contribution of marketing innovations on art organization performance: cases from the biggest art organizations in Greece. International Journal of Nonprofit and Voluntary Sector Marketing, 21(3), 133-147.

Tyagi, S., Choudhary, A., Cai, X., \& Yang, K. (2015). Value stream mapping to reduce the lead-time of a product development process. International Journal of Production Economics, 160, 202-212.

Varadarajan, R. (2017). Innovating for sustainability: a framework for sustainable innovations and a model of sustainable innovations oreintation. Journal of the Academy of Marketing Science, 45(1), 14-36.

Vázquez, R., Santos, M. L., \& Alvarez, L. I. (2001). Market orientation, innovation and competitive strategies in industrial firms. Journal of strategic marketing, 9(1), 69-90.

Verganti, R., \& Öberg, T. (2013). Interpreting and envisioning - A hermeneutic framework to look at radical innovation of meanings. Industrial Marketing Management, 42(1), 86-95.

Verhoef, P. C., Kannan, P. K., \& Inman, J. J. (2015). From multi-channel retailing to omnichannel retailing: introduction to the special issue on multi-channel retailing. Journal of retailing, 91(2), 174-181.

Veryzer, R. W. (2005). The roles of marketing and industrial design in discontinuous new product development. Journal of Product Innovation Management, 22(1), 22-41.

Vicente, M., Abrantes, J. L., \& Teixeira, M. S. (2015). Measuring innovation capability in exporting firms: The INNOVSCALE. International Marketing Review, 32(1), 29-51.

Wang, Y., Hsiao, S. H., Yang, Z., \& Hajli, N. (2016). The impact of sellers' social influence on the co-creation of innovation with customers and brand awareness in online 
communities. Industrial Marketing Management, 54, 56-70.

Weerawardena, J. (2003). The role of marketing capability in innovation-based competitive strategy. Journal of Strategic Marketing, 11(1), 15-35.

Weerawardena, J., Mort, G. S., Salunke, S., Knight, G., \& Liesch, P. W. (2014). The role of the market sub-system and the socio-technical sub-system in innovation and firm performance: a dynamic capabilities approach. Journal of the Academy of Marketing Science, 43(2), 221-239.

Weerawardena, J., \& O'Cass, A. (2004). Exploring the characteristics of the market-driven firms and antecedents to sustained competitive advantage. Industrial Marketing Management, 33(5), 419-428.

Wei, Y. S., \& Wang, Q. (2011). Making sense of a market information system for superior performance: The roles of organizational responsiveness and innovation strategy. Industrial Marketing Management, 40(2), 267-277.

Wiersema, F. (2013). The B2B agenda: The current state of B2B marketing and a look ahead. Industrial Marketing Management, 42(4), 470-488.

Wong, S. (2013). The role of management involvement in innovation. Management Decision, 51(4), 709-729.

Yan, R., Pei, Z., \& Myers, C. (2016). Do channel members value the multiple-cooperation strategy? Journal of Retailing and Consumer Services, 30, 84-95.

Yeniyurt, S., Henke Jr, J. W., \& Yalcinkaya, G. (2014). A longitudinal analysis of supplier involvement in buyers' new product development: Working relations, interdependence, co-innovation, and performance outcomes. Journal of the Academy of Marketing Science, 42(3), 291-308.

Zhang, Z., \& Hou, Y. (2017). The effect of perceived risk on information search for innovative products and services: the moderating role of innate consumer innovativeness. Journal of Consumer Marketing, 34(3), 241-254.

Zhang, J., \& Zhu, M. (2016). Market orientation, product innovation and export performance: evidence from Chinese manufacturers. Journal of Strategic Marketing, 24(5), 377-397.

Zhou, K. Z., Yim, C. K., \& Tse, D. K. (2005). The effects of strategic orientations on technology-and market-based breakthrough innovations. Journal of Marketing, 69(2), 
42-60. 